
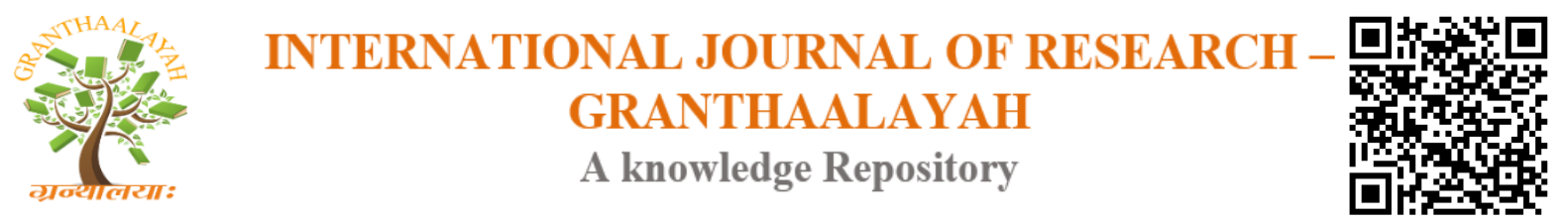

Science

\title{
ORGANIC PLASTICS: MATERIAL FOR SICK BUILDING SYNDROME CONTROL AND PREVENTION IN BUILDING CONSTRUCTION
}

\author{
Dr. Obi Ifeanyi Chukwudi ${ }^{* 1}$ \\ ${ }^{*}$ Assistant Professor, Department of Architecture, Girne American University Cyprus
}

\begin{abstract}
Plastics are organic materials, which consist of synthetic or natural high-molecular compounds (polymers). Due to the large variety of plastic, its different types have different properties, which make it possible to widely use this material in all fields of industry from packaging to the construction industry. The second highest consumer of organic plastics materials after packaging is the construction industry. Thanks to great versatility, cost effectiveness, durability, strength to weight ratio and low maintenance plastics appear to be economically attractive in the construction sector and are used in the manufacturing of wide range of materials in the construction industry. Plastics most times are not easily seen in buildings, but they are widely used in construction and building industry for a vast and wide range of materials, which include insulation, piping, interior design, piping and conduit (rain water, electrical conduits, and sewage pipes, gas distributions and plumbing). Piping and Conduit for instance can consume around 35\% of plastic production and are one of the largest consumers of polymers in construction. The purpose of this research is to study plastic as a construction material that can be used to control the formation of Sick building syndrome in buildings, and also as a material that can often be used in the construction industry.
\end{abstract}

Keywords: Organic; Plastics; Construction; SBS; Polymers.

Cite This Article: Obi Ifeanyi Chukwudi. (2018). "ORGANIC PLASTICS: MATERIAL FOR SICK BUILDING SYNDROME CONTROL AND PREVENTION IN BUILDING CONSTRUCTION." International Journal of Research - Granthaalayah, 6(6), 193-199. https://doi.org/10.29121/granthaalayah.v6.i6.2018.1365.

\section{Introduction}

There has been a rapid and dramatic increase in the population of people around the globe over the last five decades and this has become part of the existing reality in developing nations, which has resulted to high level of demand for affordable buildings. The basic meaning of building constitutes any structure that is useful in supporting occupancy or sheltering while construction has to do with the utilization of different materials for the creation of different structures (buildings). The increased-rate of demand for buildings has resulted to the rapid growth of advancements in its knowledge and building construction is now considered to be one of the largest industries in the world. The rapid growth in the population of people also resulted to the massive 
need of buildings, which also led to the demand for affordable building materials. Plastics and polymers have been regarded to be accessible easily with abundant of advantages. Plastics are playing significant role in the field of infrastructure and building leading to the reason why this sector has become the second highest consumers of plastics. There are various ways at which plastics can be used ranging from structural to non-structural uses in both inside and outside of the building such as valves, fittings and pipes (Anthony Nkem Ede 2015, p.23).

In addition, Plastics have been able to gained prominent reputation for aesthetics, high performance, durability and superior corrosion resistance. These are combined qualities of plastics with its high strength-to-weight ratio for the production of materials usable for bridge construction, solid reinforcement rods, easily-installed replacement for decking and strengthening of defective structures (Ede, A.N. 2008, p.189). The form work systems of plastics are defined to be driving transformation or renovation for expeditious and high-rate of quality construction for different groups in the society and plastics panelling materials have been found effective in improving aesthetic and speedy works. Polyurethane and amplified polystyrene that constitute the family of plastics are useful in energy conservation and found essential in the creation of green built spaces. In addition, in terms of roofing, plastic materials and plastic coatings are decreasing the consumption of energy (Anthony Nkem Ede 2015, p.23).

The purpose of this research is to study plastic, as a material often used in construction. Attempt shall also be made to look through its advantages over other materials in the control of certain ailments on occupants of buildings which are caused by harmful materials or elements found in building materials, to understand why people should more often choose plastics rather than traditional materials, such as metal, wood, or ceramics. These ailments are known as the SBS (Sick Building Syndromes).

\section{History of Plastic}

The use of plastic has increased with its development from simple natural plastic materials such as gum, chewing and shellac to polymerized natural materials such as; collagen, natural rubber and galalite and to synthetic molecules, which is the final stage such as, polyvinyl chloride, Bakelite and epoxy. The development of plastic got a big push in 1800 while evolution of industrial chemistry during Industrial Revolution. At that time an American self-taught chemist and engineer Charles Goodyear discovered the vulcanization to thermoset materials, which was derived from natural rubber. In 1862 at the Great International Exhibition in London presented "Parkesine" (nitrocellulose), which was the first man-made plastic. It was patented by a metallurgist and inventor Alexander Parkes. However, the advent of modern plastic industry could be traced back to early years of 20th century, when both people and industrialists advertently admitted this material in their lives. In addition, the creation and promulgation of two plastic compounds in 1907 and 1908, which are Cellophane created by Jacques E. Brandenberger and Bakelite created by Leo $\mathrm{H}$. Baekeland also marked the emergence of modern plastic industry (Bellis, 2012, p.1-2). 


\section{Plastic in Modern Architecture}

Previously, many architects preferred more traditional materials such as metal, wood, etc., which were considered stronger and more durable. Nowadays, some kinds of plastics are in no way inferior to other materials in terms of strength, durability or aesthetics. "It is used in the form of a thin film, easily blending sheets, cast elements and in general, it responds to almost any task of the project and the need of the architect. In addition, it has a glossy, futuristic look, which cannot be achieved from natural material. One example of a plastic material commonly used in architecture - ETFE (Ethylene tetrafluoroethylene), which is usually used as architectural glass. DuPont developed ETFE in 1970s in forms of lightweight and heat resistant film for the aerospace industry. This material has high strength; it does not age from prolonged light and atmospheric exposure. ETFE has got high rate of durability and easily recyclable with the ability to hold up extreme climatic conditions. It requires less energy in its manufacturing and transportation process due to its light weight feature. ETFE can as well effectively work during natural disasters such as earthquakes because of its elasticity feature and it is cost-effective to produce. ETFE film was used in several architectural projects such as the national swimming centre in Beijing, the Munich football stadium Allianz arena, the Eden project in the UK and others.

\section{Plastic-Based Building Materials}

According to Berge (2001) plastic is defined as a substance containing natural or synthetic high rate of molecular organic material that is liquefiable and able to be casted in different moulds. The first use of plastic in building and construction was basically as ornament, superficial finish or secondary parts for enclousure systems. It should be noted that in spite of the various uses of plastics in construction industry such as for glazing, plumbing fixtures, finishes and as structural component in the present era, they recently began to gain special recognition and respect as usable primary material. However, plastics offer many significant advantages such as cost effective or affordable cost, lightweight, energy saving and impervious to moisture and corrosion (Bell 2006).

Plastics can be classified into two parts, which are thermo plastics and thermosetting plastics and both types of plastics are useful for building. Thermosetting set of plastics are considered to be stronger than thermoplastics. They have different ways of applications such as rigid foam insulation, adhesive, membrances of waterproofing, laminates, and frames for window. There are three types of thermoplastics that are commonly used in building construction, which include; acrylic, polyvinyl chloride (PVC) and polycarbonate. The most often used is PVC because of its peculiarities, which are; water resistant, affordable prices and resistance to tearing (Bell 2006). All the three types of plastics can be used for sheeting and sheeting is useful for damp-proofing of foundations and moisture-proofing. In sealing strips, the commonly used set of plastics are ethylene-propylene rubber, chloroprene rubber, polyamide, PVC and silicone rubber (Berge 2001). It is not very often to use plastics as building structural materials but findings have reviewed that there is a waste of huge quantity of unspecified plastics in the western world that can be used as raw materials for simple structural elements. In addition, plastics or polymer-based building materials are most often used materials for crack repair considering the good features of epoxy resins and its durability whenever it is used as materials for repair. Calder and Thompson analysis reviews that the conventional structural performance of reinforced concrete slabs that are repaired 
with the use of epoxy resin outperform those that use other materials (Esin Kasapoğlu 2008, p.23).

Plastic based-building materials have better versatility because of the flexibility in restructuring them, they perform special functions such as light weight, corrosion resistance, durability and low rate of maintenance requirements. Woodplastic Composites (WPCs) means the combination of wood fibers and plastics and they are most often used at where there is a need for high rate of durable performance. WPC lumber can not easily cracks, rot and warps if it is effectively manufactured and adequately installed (Krebs 2006). There is also an high rate of thermal expansion in PVC and polycarbonates as well as higher thermal movement in diverse of polyethylene.

\section{Advantages of Plastic-Based Building Materials}

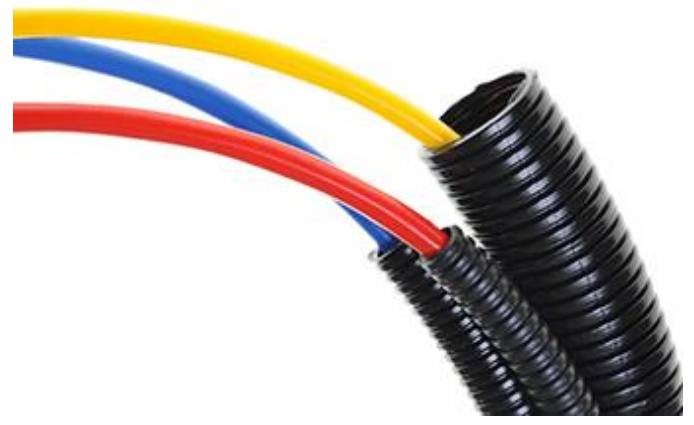

Corrosion Resistant and Durability: plastics are used as window frames and pipes due to their high level of durability. They also have an impressive life span covering around one hundred years as plastic pipes and more than 50 years as exterior cables because they have anti-corrosion properties.

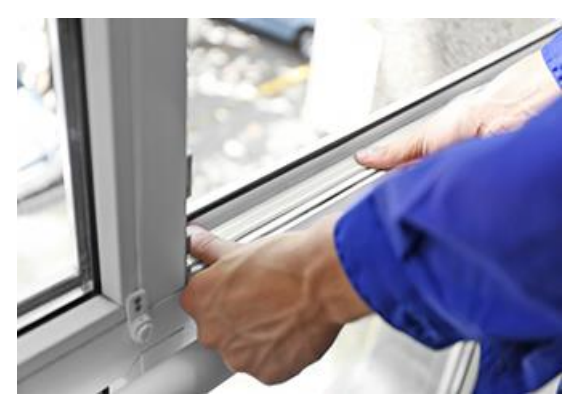

Insulation: Plastics are capable of providing effectual insulation from cold and heat, they can prevent energy leakage and enable energy saving in an household. They can also prevent noise pollution.

Cost Effectiveness: plastic components are less expensive and more affordable than traditional materials for production and installment. They offer great value for money. Plastic components are mostly more economical to produce. 
Hygiene: plastic pipes provide better hygienic and safe transportation of water. They are recommendable for hygienic household surfaces and coverings of floor because they can be easily taken care of.

Innovation: Plastics have become an inspiration for architects to design innovative buildings, creative features and dimensions. The rapid advancement in plastics innovation have been found helpful in cost reduction and increment in the quality of buildings.

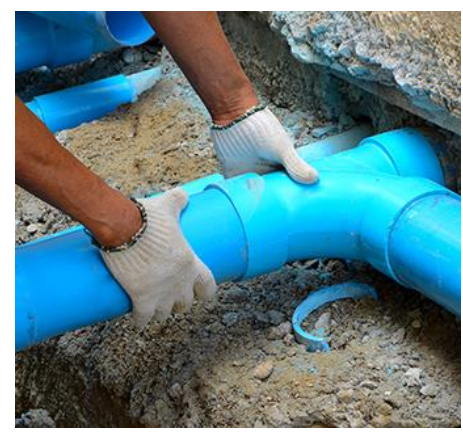

Easy to Install and Maintain: plastics can be installed easily with less requirements of management and impenetrable. They are light in weight and their flexibility enables the possibility of soil movements in plastic pipes.

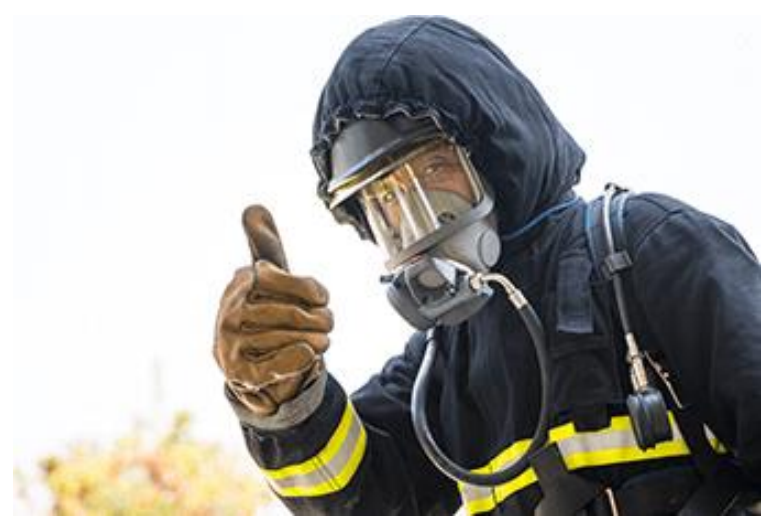

Fire safety: the advancement in polymer-based building materials in construction sector is valued because of their quality of fire resistance. Plastics and PVC are most often used as smoke detectors, alarms and automated firefighting systems as a result of their fire safety features.

\section{How does plastic in construction help in reducing risk of ailments on occupants?}

\section{Corrosion}

The presence of iron in drinking water, not passed through filters for de-ironing, worsens its taste and smell; it stains the water in a brown color. With the regular use of such water, the risk of various diseases of the internal organs increases, primarily the liver and kidneys. In addition, excess iron adversely affects the human skin, the morphological composition of the blood, can cause allergic reactions, and also contributes to the accumulation of sediment in the drainage system. Similar information can be presented for manganese. Iron can enter drinking water not 
only in natural conditions but also as a result of corrosion apparatuses and pipelines. At present, many pipelines are made of plastic because of its resistance to corrosion in contrast to metals.

\section{Mold}

Residents of cities spend in their apartments $50-70 \%$ of their time, and in closed premises up to $80-90 \%$ of the time. During this time, the air in the room is filtered through the respiratory tract and if it contains a large number of microorganisms, they settle in the lungs (and the cells of the molds can penetrate deeply into the lung tissue), causing various painful conditions. These conditions can be described by a term 'Sick building syndrome'. And mold has a very negative effect on a human's body. Some types of fungi can cause diathesis, allergies that can lead to asthma and even cancer diseases. Nowadays more often people use plastic instead of wood, which is highly affected by fungi. Plastic, on the contrary, does not get rot.

\section{Conclusion}

The use of plastics (polymers) materials in building and construction industries has gained special attention and recognition due to its enormous advantages over other traditional building and construction materials as it has been explained. There are many available sources in the literature explaining the various ways at which plastics-based building materials have been found preferable in terms of their inherent peculiarities, significance and applications. This research has also stated these conventional benefits of using plastic materials in building and construction industries following these established facts in the existing literature. In addition, this research has also examined the various ways at which the use of plastics-based building materials could prevent the possibility of Sick Building Syndrome in building constructions. Sick Building Syndrome is a term that generally covers the situation at which people living a building are suffering from some symptoms of illness without any apparent reason. The intensity of these symptoms increases base on the duration of time spent in the building. Occupants of the building might basically complain about symptoms such as cough; headache, chest tightness, muscle aches fever etc. These symptoms are identified with the building in a situation whereby building occupants stop experiencing the building related illness (BRI) after evacuating the building. There are many reasons why a building could possess such terrific features and discussion of these reasons is not under the scope of this paper. This research only aims to explain how the use of plastic-based building materials could also prevent the possibility of SBS, which has already been explained in this research paper.

\section{References}

[1] Anthony Nkem Ede (2015). Acceptability of Plastic Materials for Structural Applications in Nigerian Buildings. International Journal of Innovative Research in Advanced Engineering Issue 3, Volume 2, p.23-25.

[2] Bell, V. B., (2006), 'Materials for architectural design', Laurance King Publishing, London, UK.

[3] Bellis, (2012). The History of Plastics: Timeline of Plastics. Available at http://www.thebuttonmonger.com/cof_Plastics.pdf. Accessed on 05-06-2018, p.1-2

[4] Berge, B., (2001), 'The ecology of building materials', Architectural Press Elsevier Science Ltd., Oxford, UK. 
[5] Bolshev, R. Potolovsky, E. Pustovalov, "Investigation of negative exposure of corrosion to the human organism”. Volgograd State University of Architecture and Civil Engineering, Volgograd, Russia, p. 101-103.

[6] Ede, A.N. (2008). Structural Damage Assessment of FRP-Strengthened Reinforced Concrete Beams under Static and Fatigue Loads. Department of Innovative Engineering, Lecce, Italy: University of Salento, p.189.

[7] Esin Kasapoğlu (2008). Polymer-based Building Materials: Effects of Quality on Durability. 11DBMC International Conference on Durability of Building Materials and Components ISTANBUL, Turkey, p.2-3

[8] Krebs R., (2006), 'Composites as high-performance solutions', Modern Materials, Volume 4, Issues1, p.21-25.

[9] Lynch Patrick. (2016). "ETFE: The Rise of Architecture's Favorite Polymer". Available at https://www.archdaily.com/784723/etfe-the-rise-of-architectures-favorite-polymer. Accessed on 04-03-2018.

[10] Mewada Abhishek. (2015). "Building materials as a plastic". Available at https://www.slideshare.net/abhishekmewada54/building-materials-as-a-plastic, Accessed on 0304-2018

*Corresponding author.

E-mail address: ifeanyiobi2@gmail.com 